Wildan Army, Maya Sari

Vol 6 No 1

ISSN : 2541-6995

E ISSN : 2580-5517

\title{
PENGARUH LIKUIDITAS DAN SOLVABILITAS TERHADAP KEPUTUSAN LINDUNG NILAI
}

\author{
${ }^{1}$ Wildan Army Abdillah \\ ${ }^{2}$ Maya Sari \\ Program Studi Manajemen, Sekolah Pascasarjana, Universitas Pendidikan Indonesia \\ wildanarmy@upi.edu mayasari ${ }^{1}$ mayasari@upi.edu ${ }^{2}$
}

\begin{abstract}
ABSTRAK
Penelitian ini bertujuan untuk mengetahui pengaruh likuitas, solvabilitas terhadap keputusan lindung nilai pada perusahaan pertambangan di Bursa Efek Indonesia periode 2016-2019 dengan menggunakan regresi logistik biner. Jumlah populasi dalam penelitian ini adalah 41 perusahaan pertambangan yang terdaftar di Bursa Efek Indonesia periode 2016-2019. Jenis data yang digunakan adalah data sekunder yang diperoleh dari Bursa Efek Indonesia. Hasil pengujian signifikan secara simultan terdapat pengaruh likuidtas dan solvabilitas terhadap keputusan lindung nilai, sedangkan secara parsial variabel likuiditas berpengaruh signifikan sementara solvabilitas tidak berpengaruh signifikan terhadap keputusan lindung nilai.

Kata kunci: keputusan lindung nilai, likuiditas, dan solvabilitas
\end{abstract}

\section{PENDAHULUAN}

Penilaian nilai mata uang dari perspektif mata uang dari negara lain dengan menggunakan konsep nilai tukar atau kurs (M. M. Hanafi \& Halim, 2009). Nilai tukar mata uang dapat dikatakan sebagai banyaknya mat uang suatu negara atau domestic yang wajib dikeluarkan guna mendapatkan satu unit mata uang asing. Risiko kurs akan timbul akibat ketidakpastian nilai tukar yang terjadi karena fluktuasi niali tukar dari ketidakseimbangan permintaan dan penawaran dari suatu mata uang asing (Griffin, Ricky, Pustay, \& W, 2005). Ketidak terduagaan perubahan nilai mata uang dapat berdampak pada penjualan, harga, laba eksportir dan importir. Hal tersebut menjadi risiko utama pada perusahaan yang terlibat dalam transaksi multinasional.

Pada dasarnya adanya perdagangan multinasional mendorong peningkatan persaingan dan fluktuasi harga pasar yang meningkatkan ketidakpastisan bisnis atau risiko dalam 
Wildan Army, Maya Sari

Vol 6 No 1

ISSN : 2541-6995

E ISSN : 2580-5517

mempertahankan bisnis. Perubahan nilai mata uang asing yang diakibatkan oleh fluktuasi kurs valuta asing.

Adanya pergerakan nilai tukar rupiah yang memungkinkan berdampak pada ketidakberuntungan, dengan mengingat hutang luar negeri Indonesia yang didominasi oleh Dollar AS semakin meningkat. Aktivitas perdagangan internasional yang menggunakan valuta asing dalam transasksi ekspor maupun impor sehingga perusahaan memiliki risiko terkena dampak dari eksposur valuta asing. Ketika IDR mengalami penurunan atau dapat dikatakan USD terapresiasi, maka akan berdampak pada mahalnya harga impor barang dan mengakibatkan harga barang mahal pula (Mishikin, 2008).

Eksposur akuntansi, eksposur ekonomi, eksposur transaksi, eksposur valuta asing adalah eksposur yang akan dihadapi oleh para perusahaan perdagangan multinasioanal (M. Hanafi, 2009). Eksposur sebagai tingkat arus kas yang terpengaruhi oleh perubahan nilai tukar (Paranita, 2011). Risiko terbesar yang dihadapi oleh perusahaan multinasional berupa eksposur valuta asig (Dumas, 1978; Levi, 1990; Shapiro, 1975) (Shapiro, 1975) dalam (Du \& Hu, 2012) menyarankan bahwa perubahan valuta asing dapat mempengaruhi arus kas perusahaan. Adanya dampak negatif dari risiko fluktuasi kurs valuta asing serta menjaga kepentingan para pemegang saham, maka perusahaan multinasional perlu mengantisipasi dengan melakukan kebijakan hedging dengan instrument derifatif valuta asing (Paranita, 2011).

Secara empiris variabel rasio likuiditas berpengaruh terhadap keputusan hedging sesuai dengan penelitian (Ahmad, Mardiyati, \& Nashrin, 2015; Livingstone \& Ngugi, 2017; Mediana \& Muharam, 2016) dan rasio solvabilitas berpengaruh terhadap keputusan hedging sesuai dengan hasil penelitian (Chaudhry, Mehmood, \& Mehmood, 2014; Mediana \& Muharam, 2016)

\section{METODE PENELITIAN}

Dalam penelitian ini, populasi yang digunakan adalah perusahaan pertambangan yang terdaftar di BEI, dengan sampel yang dipilih sebanyak 41 perusahaan dengan menggunakan data tahun 20162019. Dalam penelitian ini menggunakan uji regresi logistik, pertama untuk melihat eksposur ekonomi suatu perusahaan dapat dilihat dengan model.

$L=\operatorname{Ln}\left(\frac{p t}{1-p t}\right)=b 0+b 1 C R+b 2 D E R+e t$ 
Wildan Army, Maya Sari

Vol 6 No 1

ISSN : 2541-6995

E ISSN : 2580-5517

Dimana Log perusahaan yang membuat keputusan lindung nilai dan tidak menggunakan keputusan lindung nilai. Dan pada tahap analisis regresi logistik berisi pengujian terhadap keseluruhan model. Statistik yang digunakan didasarkan pada fungsi kemungkinan. Kemungkinan L dari model adalah probabilitas bahwa model yang dihipotesiskan menggambarkan data input. Untuk menguji hipotesis nol dan alternatif, L ditransformasikan menjadi -2 Log (Ghozali, 2018)

Selanjutnya dilakukan uji koefisien determinasi (Cox and Snell's R square) Merupakan ukuran yang mencoba meniru ukuran 2 pada regresi berganda yang didasarkan pada teknik estimasi likelihood dengan nilai maksimum kurang dari 1 (satu) sehingga sulit untuk ditafsirkan. Nagelkerke's R square merupakan modifikasi dari koefisien Cox dan Snell untuk memastikan bahwa nilainya bervariasi dari 0 (nol) hingga 1 (satu). Ini dilakukan dengan membagi nilai Cox dan Snell2 dengan nilai maksimum. Nilai 2 Negelkerke dapat diartikan sebagai nilai 2 pada regresi berganda (Ghozali, 2018).

Kemudian melakukan uji kelayakan model regresi (Hosmer and Lemeshow's Goodness of Fit Test) pengujian hipotesis nol dan data empiris fit or fit model (tidak ada perbedaan fit antara model dan data sehingga model dapat dikatakan fit ). Jika nilai uji statistik Goodness-of-fit Hosmer dan Lemeshow sama dengan atau lebih kecil dari 0,05, maka hipotesis nol ditolak yang berarti terdapat perbedaan yang signifikan antara model dengan nilai observasinya. Jika nilai statistik Hosmer and Lemeshow's Goodness-of fit test lebih besar dari 0,05, maka hipotesis nol tidak dapat ditolak dan berarti model tersebut mampu memprediksi nilai observasinya atau dapat dikatakan model diterima karena model tersebut cocok dengan data observasi (Ghozali, 2018),

Dalam pengujian hipotesis penelitian dilakukan uji signifikansi model simultan (Omnibus Test of Model Cofficients) menunjukkan signifikansi model regresi biner logistik yang diperoleh dari hasil penelitian. Jika nilai Sig $<\mathrm{a}=0,05$ maka dapat diasumsikan bahwa paling tidak ada satu variabel independen yang mempengaruhi model (Pramesti, 2013) dan secara parsial menguji signifikansi model (Uji Wald). Hal ini dilakukan sama dengan uji t pada regresi linier berganda, yaitu untuk mengetahui apakah koefisien variabel bebas pada model logit berbeda dengan 0 atau tidak. . Dari uji statistik Wald ini dapat diketahui apakah variabel bebas mempengaruhi variabel terikat dalam model regresi logistik (Widarjono, 2015).

\section{Jenis Penelitian}


Wildan Army, Maya Sari

Vol 6 No 1

ISSN : 2541-6995

E ISSN : 2580-5517

Jenis data penelitian yang digunakan untuk mendukung penelitian ini merupakan data kuantitatif, yaitu data yang diperoleh berupa angka-angka dan analisis dengan menggunakan statistik. Dalam penelitian ini data yang diperoleh merupakan data yang sesuai dengan rumusan masalah yang telah diuraikan, yaitu data yang berhubungan dengan likuiditas, solvabilitas serta keputusan lindung nilai.

\section{Waktu dan Tempat Penelitian}

Penelitian ini berfokus kepada perusahaan pertambangan di Bursa Efek Indonesia periode 20162019 dengan menggunakan regresi logistik biner. Jumlah populasi dalam penelitian ini adalah 41 perusahaan pertambangan yang terdaftar di Bursa Efek Indonesia periode 2016-2019.

\section{Target/Subjek Penelitian}

Sumber data penelitian yang digunakan dalam penelitian ini adalah sumber data sekunder. Pada penelitian ini, data diperoleh dari Laporan tahunan yang dipublikasi melalui website Bursa Efek Indonesia idx.co.id

\section{Teknik Analisis Data}

Metode analisis data merupakan kegiatan penelitian yang didasarkan pada ciri-ciri keilmuan yaitu rasional, empiris, dan sistematis untuk mendapatkan data dengan tujuan kegunaan tertentu (Sugiyono, 2017). Penelitian ini menggunakan analisis regresi logistik. Adapun analisis yang digunakan adalah analisis statistik deskriptif, uji normalitas serta analisis regresi logistik.

\section{HASIL PENELITIAN DAN PEMBAHASAN (TIMES NEW ROMAN (TNR-12) BOLD)}

Sebelum membahas temuan utama penelitian ini, peneliti menyajikan statistik deskriptif variabel pada Tabel 1. Dari data pada Tabel 1 terlihat bahwa nilai likuiditas yang diproksikan dengan current ratio terendah adalah 0,01 sedangkan nilai tertinggi adalah 146,13 dengan rata-rata 3,6437 dan standar deviasi 14,64660. Sedangkan solvabilitas yang diproksikan dengan debt to equity ratio memiliki nilai terendah sebesar -20,79 dengan nilai tertinggi sebesar 21,19 dan rata-rata sebesar 1,1290 .

Bagian ini menyajikan hasil penelitian. Hasil penelitian dapat dilengkapi dengan tabel, grafik (gambar), bagan atau deskriptif. Tabel dituliskan di tengah atau di akhir setiap teks deskripsi hasil/perolehan penelitian. Judul Tabel ditulis dari kiri, semua kata diawali huruf besar, kecuali kata sambung. Kalau lebih dari satu baris dituliskan dalam spasi tunggal (at least 12). Sebagai contoh, dapat dilihat Tabel 1. berikut. 
Wildan Army, Maya Sari

Vol 6 No 1

ISSN : 2541-6995

E ISSN : 2580-5517

Tabel 1 Statistik Deskriptif

\begin{tabular}{lllll}
\hline Variabel & Minimum & $\begin{array}{l}\text { Maksimu } \\
\mathbf{m}\end{array}$ & $\begin{array}{l}\text { Berar } \\
\text { ti }\end{array}$ & $\begin{array}{l}\text { Standar } \\
\text { Deviasi }\end{array}$ \\
\hline CR & .01 & 146.13 & 3.6437 & 14,64660 \\
DER & -20.79 & 21.19 & 1.1290 & 3.55222
\end{tabular}

Tabel 2 Model Keseluruhan (Kecocokan Model Secara Keseluruhan)

\begin{tabular}{lll}
\hline Pengulangan & -2 Log kemungkinan & $\begin{array}{l}\text { Koefisien } \\
\text { Konstan }\end{array}$ \\
Langkah 0 & 162.935 & -1.220 \\
1 & 161,892 & -1.406 \\
2 & 161,889 & -1.417 \\
3 & 161,889 & -1.417 \\
\hline
\end{tabular}

Tabel 3 Hasil Uji Kecocokan Model Keseluruhan Overall

\begin{tabular}{lrllll}
\hline \multicolumn{5}{c}{ Pengulangan } & \multicolumn{2}{l}{$\begin{array}{l}\text { kemungk } \\
\text { inan }\end{array}$} & Koefisien & & \\
Langkah & 1 & 157.837 & -1.020 & -131 & .043 \\
1 & 2 & 154.110 &,- 980 & -284 & .050 \\
& 3 & 153.523 & -833 & -.400 & .044 \\
& 4 & 153,497 & -797 & -430 & .042 \\
& 5 & 153,497 & -795 & -.431 & .042 \\
& 6 & 153,497 & -795 & -.431 & .042 \\
\hline
\end{tabular}

Dari data di atas menunjukkan bahwa model yang digunakan dalam penelitian ini menunjukkan bahwa model tersebut dapat digunakan pada faktor-faktor yang dapat mempengaruhi keputusan hedging. Atau jelas keputusan hedging perusahaan pertambangan di Indonesia 2016-2019, likuiditas dan solvabilitas bisa menjadi faktor yang mempengaruhinya, jika semua faktor ini disatukan. Keputusan lindung nilai perusahaan dapat terjadi sebagai akibat dari perubahan nilai tukar mata uang. 
Wildan Army, Maya Sari

Vol 6 No 1

ISSN : 2541-6995

E ISSN : 2580-5517

Namun jika secara parsial terdapat faktor yang tidak dapat secara langsung mempengaruhi keputusan hedging yaitu debt to equity ratio. Pada hasil pengujian yang dilakukan, rasio solvabilitas yang diproksikan dengan DER tidak dapat mempengaruhi keputusan hedging dengan tingkat signifikansi yang lebih besar dari yang ditentukan (Chaudhry et al., 2014; Hamali, 2016; Seng \& Thas Thaker, 2018).

Berbeda dengan likuiditas perusahaan, dalam penelitian ini ditemukan bahwa likuiditas perusahaan merupakan salah satu faktor dalam keputusan hedging bagi perusahaan pertambangan di Indonesia sejalan dengan (Ahmad et al., 2015; Livingstone \& Ngugi, 2017; Mediana \& Muharam, 2016) menyatakan bahwa likuiditas berpengaruh signifikan terhadap keputusan lindung nilai.

\section{KESIMPULAN DAN IMPLIKASI}

Berdasarkan hasil penelitian yang telah dilakukan dengan menggunakan uji regresi logistik, diperoleh kesimpulan bahwa likuiditas dan solvabilitas secara bersama-sama dapat menjadi faktor dalam keputusan lindung nilai. Namun hanya secara parsial likuiditas berpengaruh signifikan terhadap keputusan lindung nilai, sedangkan solvabilitas tidak berpengaruh signifikan terhadap keputusan lindung nilai.

\section{DAFTAR PUSTAKA}

Ahmad, G. N., Mardiyati, U., \& Nashrin, A. S. (2015). Analysis of Hedging Determinants With Foreign Currency Derivative Instruments on Companies Listed on Bei Period 2012-2015. JRMSI - Jurnal Riset Manajemen Sains Indonesia, 6(2), 540. https://doi.org/10.21009/jrmsi.006.2.03

Chaudhry, N. I., Mehmood, M. S., \& Mehmood, A. (2014). Determinants of corporate hedging policies and derivatives usage in risk management practices of non-financial firms. Wulfenia Journal, 21(7), 1-18.

Du, D., \& Hu, O. (2012). Foreign exchange volatility and stock returns. Journal of International Financial Markets, Institutions and Money, 22(5), 1202-1216. https://doi.org/10.1016/j.intfin.2012.07.001

Dumas, B. (1978). THE THEORY OF THE TRADING FIRM REVISITED. THE JOURNAL OF FINANCE VOL. XXXIII. NO. 3, XXXIII(3), 1019-1030.

Ghozali, I. (2018). “Aplikasi Nalisis Multivariate dengan Program IBM SPSS 25”. Edisi 9. Semarang: Universitas Dipenogoro.

Griffin, Ricky, Pustay, \& W, M. (2005). Bisnis Internasional. Edisi Keempat. Indonesia: PT. 
Wildan Army, Maya Sari

Vol 6 No 1

ISSN : 2541-6995

E ISSN : 2580-5517

Indeks Kelompok Gramedia.

Hamali, A. Y. (2016). Pemahaman Manajemen Sumber Daya Manusia. Yogyakarta:CAPS.

Hanafi, M. (2009). Manajemen Risiko, Edisi Ketiga. Yogyakarta : Unit Penerbit dan Percetakan Sekolah Tinggi Ilmu Manajemen Ykpn.

Hanafi, M. M., \& Halim, A. (2009). Analisis Laporan Keuangan. Yogyakarta: UPP STIM YKPN. Levi, M. D. (1990). International finance, 2nd ed. McGraw Hill, New York, NY.

Livingstone, K. T., \& Ngugi, K. (2017). Determinants of Corporate Hedging Practices Used By Companies. International Journal of Business Management \& Finance, 1(5), 73-92.

Mediana, I., \& Muharam, H. (2016). Analisis Faktor- Faktor Yang Mempengaruhi Pengambilan Keputusan Lindung Nilai (Hedging) Menggunakan Instrumen Derivatif. Journal Of Management, 5(2), 1-14.

Mishikin, F. (2008). Ekonomi Uang, Perbankan dan Pasar Keungan, Edisi Kedelapan. Jakarta: Salemba Empat.

Paranita, E. S. (2011). Kebijakan Hedging Dengan Derivatif Valuta Asing Pada Perusahaan Publik Di Indonesia. Seminar Nasional Ilmu Ekonomi Terapan, (32), 228-237.

Pramesti, G. (2013). Smart Olah Data Penelitian Dengan SPSS 21. Jakarta: PT Elex Media Komputindo.

Seng, C. K., \& Thas Thaker, H. M. (2018). Determinants of corporate hedging practices: Malaysian evidence. Reports on Economics and Finance, 4(4), 199-220. https://doi.org/10.12988/ref.2018.8418

Shapiro, A. C. (1975). Exchange Rate Changes, Inflation, and the Value of the Multinational Corporation. The Journal of Finance, 30(2), 485. https://doi.org/10.2307/2978728

Sugiyono. (2017). “Metode Penelitian Kuantitatif, Kualitatif, dan R\&D.” Bandung : Alfabeta.

Widarjono, A. (2015). Analisis Multivariat Terapan dengan Program SPSS, AMOS, dan SMARTPLS. Yogykarta: UPP STIM YKPN. 